\title{
VLIV DRUHU PROVZDUŠŇOVACÍCH PŘÍSAD NA VLASTNOSTI BETONU
}

\author{
EFFECT OF TYPE OF AIR-ENTRAINING ADMIXTURES ON THE \\ PROPERTIES OF CONCRETE
}

\author{
Ondřej Pikna", , Martin Ťažký², Rudolf Hela ${ }^{3}$
}

"pikna.o@fce.vutbr.cz

Vysoké učení technické v Brně, Fakulta stavební, Ústav technologie stavebních hmot a dílců, Veveří 331/95, 602 00 Brno

\begin{abstract}
Abstrakt
Jedním ze základních faktorů, které je nutno brát v potaz při navrhování betonů je i jeho trvanlivost. Prostředí, jenž je výrazně spjato s trvanlivostí zatvrdlého betonu, zahrnuje i působení záporných teplot spolu s možností kombinace s chemicky-rozmrazovacími látkami (soli). Aktuálně předkládaný článek se snaží objasnit a porovnat prakticky využívané provzdušňovací př́isady do betonu, jenž mají za cíl zlepšení vlastností, zejména trvanlivosti ve zmíněném prostředí mrazu.
\end{abstract}

\section{Klíčová slova}

Provzdušňovací přísady, póry, kamenivo, beton

\begin{abstract}
One of the elementary factor that must be taken into account when designing concrete is its durability. The exposition, which is significantly connected with the durability of hardened concrete, is also the effect of negative temperatures together with the possibility of combination with salts. The present article tries to clarify and compare the currently used air entraining admixtures for concrete, which aim to improve the properties and especially the durability in the mentioned exposition.
\end{abstract}

\section{Key words}

Air-entraining admixtures, pores, aggregate, concrete

\section{1 ÚVOD}

Obecné povědomí o provzdušněných betonech nás obklopuje již řadu let. Nebezpečí v působení záporných teplot v kombinaci se solemi tkví v hodnotách krystalizačních tlaků, kde objem ledu je asi o 9 \% větší než objem vody. $\mathrm{S}$ podporou růstu krystalů chemických solí tvoří pak značné, destruktivní účinky. Podle některých autorů je dokonce dle Clausiovy-Clapeyronovy rovnice potřeba překonat 13,2 MPa krystalizačního tlaku na každý stupeň pod $0{ }^{\circ} \mathrm{C}$, aby bylo zabráněno poškození. Mezi nejvíce namáhanými betony bývají často konstrukční části dopravní infrastruktury (mostovky, CB kryty apod.) či prefabrikované betonové zboží vystavené přímo působení CHRL (betonové bloky, ploché dlažby, betonové obrubníky, svodidla aj). Mezi možnosti, jak předejít zmíněným účinkům mrazu, může patřit samotná skladba směsi, tedy použití kvalitních vstupních surovin (nízké množství odplavitelných částic, zejména jílovitých u kameniva apod.), vhodná konzistence směsi či vhodná křivka zrnitosti směsi kameniva [1].

Jako velmi účinnou možnost ochrany před zmíněnými účinky mrazu, lze jmenovat využití tzv. provzdušňovacích př́sad, které mají za cíl vytvořit sít’ rovnoměrně rozmístěných účinných mikropórů $(10-300 \mu \mathrm{m})$. Tyto mikropóry vytváŕí účinný prostor pro eliminaci nebezpečného krystalizačního tlaku vznikajícího ledu. Účinek těchto mikropórů je připisován jejich velikosti, kdy voda vniknutá do tohoto prostoru díky svému povrchovému napětí nedokáže prostor zcela vyplnit a uvnitř mikropóru tak vzniká prostor pro expanzi ledu a vznikajících krystalů soli. Rovnoměrně rozložené mikropóry v betonovém kameni navíc rozrušují sít' nežádoucích kapilár a propojené pórové struktury kompozitu.

V předkládaném článku budou zmíněny dva druhy dle převažující zastoupené chemické báze. Prvním druhem jsou syntetické tenzidy, dalším pak provzdušňovací př́isady na bázi přírodních pryskyřic [1]. 
Jedná se o povrchově aktivní látky, jenž mají schopnost snížit povrchovou energii nebo napětí na rozhraní vzduch a voda. Podle polarity je lze rozdělit pak na aniontové, kationtové či neiontové.

\section{CÍLE}

Primárním cílem experimentu bylo porovnat a objasnit chování dvou druhů provzdušňovacích př́isad používaných v betonářské praxi při různém dávkování s cílem optimalizace s ohledem na fyzikální, mechanické a trvanlivostní parametry betonu. Nejprve bylo navrženo několik betonových směsí při zachování konstantních vstupních surovin všech receptur. Došlo k namíchání několika variant s různým množství obsahu vzduchu v čerstvém betonu vzniklém díky př́idavku daného druhu provzdušňovací př́ísady.

\section{POUŽITÉ SUROVINY}

Celkem byly použity dva druhy provzdušňovacích přísad s různou chemickou bází. První byla na bázi přírodních pryskyřic s obchodním názvem Mapeair AE 1, druhá pak na bázi syntetických tenzidů s obchodním názvem Mapeair LP X7. Základní receptura navržených betonů obsahovala portlandský cement CEM I 42,5 R z produkce závodu Mokrá. Prané kamenivo ve frakcích 0/4, 4/8 a 8/16 mm bylo použito těžené z lokality Žabčice. Plastifikační přísada byla použita od společnosti Mapei na bázi PCE s obchodním označením Dynamon RC 730. Celkem byly namíchány 3 receptury s různým obsahem vzduchu v čerstvém betonu s př́ísadou na bázi přírodních pryskyřic a 3 receptury $\mathrm{s}$ různým obsahem vzduchu $\mathrm{s}$ přísadou na bázi syntetických tenzido̊. Všechny receptury lze vidět v následující tabulce Tab. 1 . Z pohledu experimentu nebyl přepočítáván skutečný objem betonu dle obsahu vzduchu v čerstvém betonu, ale pro výpočet byla použita střední hodnota, tedy 5,5\%.

Tab. 1 Receptury provzdušněných betonů.

DTK = drobné těžené kamenivo, HTK = hrubé těžené kamenivo.

\begin{tabular}{|c|c|c|c|c|c|c|c|}
\hline $\begin{array}{c}\text { Receptura } \\
{\left[\mathrm{kg} / \mathrm{m}^{3}\right]}\end{array}$ & $\begin{array}{c}\text { Množství } \\
\text { vzduchu v } \\
\text { čerstvém } \\
\text { betonu [\%] }\end{array}$ & $\begin{array}{l}\text { CEM I } \\
42,5 \text { R } \\
\text { Mokrá }\end{array}$ & $\begin{array}{c}\text { DTK 0/4 } \\
\text { mm } \\
\text { Žabčice } \\
\text { (prané) }\end{array}$ & $\begin{array}{c}\text { HTK } \\
\mathbf{4 / 8} \mathbf{~ m m} \\
\text { Žabčice }\end{array}$ & $\begin{array}{c}\text { HTK } \\
8 / 16 \text { mm } \\
\text { Žabčice }\end{array}$ & $\begin{array}{c}\text { Vodní } \\
\text { součinitel } \\
{[-]}\end{array}$ & $\begin{array}{c}\text { Superplastifikační } \\
\text { príísada Dynamon } \\
\text { RC } 730\end{array}$ \\
\hline AE 3,0 & 3,0 & \multirow{7}{*}{370} & \multirow{7}{*}{910} & \multirow{7}{*}{190} & \multirow{7}{*}{660} & \multirow{7}{*}{0,42} & \multirow{7}{*}{2,3} \\
\hline AE 5,5 & 5,5 & & & & & & \\
\hline $\mathrm{AE} 8,7$ & 8,7 & & & & & & \\
\hline & & & & & & & \\
\hline LPX7 3,4 & 3,4 & & & & & & \\
\hline LPX7 5,7 & 5,7 & & & & & & \\
\hline LPX7 9,2 & 9,2 & & & & & & \\
\hline
\end{tabular}

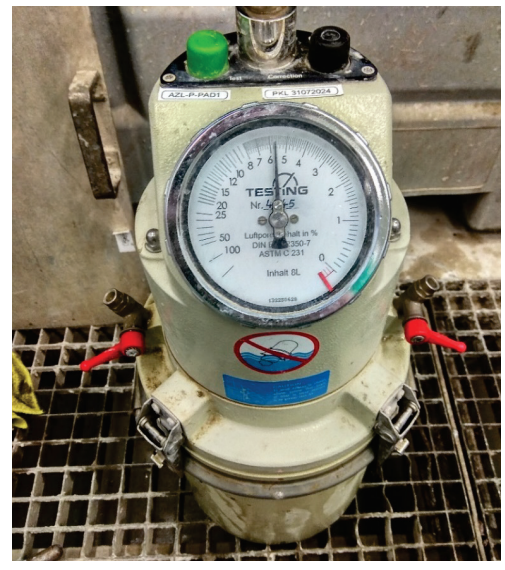

Obr. 1 Zařízení pro stanovení obsahu vzduchu v čerstvém betonu (tlaková metoda) [2]. 


\section{EXPERIMENT}

\section{Zkoušky na čerstvých betonech}

Všechny receptury byly míchány na předpokládanou konzistenci 180-200 mm sednutí kužele dle ČSN EN 12 350-2. Následně bylo provedeno stanovení objemové hmotnosti čerstvého betonu dle ČSN EN 123506 a stanovení obsahu vzduchu v čerstvém betonu pomocí tlakové metody dle ČSN EN 12350-7 (Obr. 1). V následující tabulce Tab. 2 lze vidět výsledky těchto zkoušek [2], [3], [4].

Tab. 2 Výsledky fyzikálních zkoušek čerstvých betonů.

\begin{tabular}{cccc}
\hline Receptura & $\begin{array}{c}\text { Obsah vzduchu } \\
\text { v čerstvém } \\
\text { betonu [\%] }\end{array}$ & $\begin{array}{c}\text { Objemová } \\
\text { hmotnost } \\
\text { čerstvého betonu } \\
{\left[\mathbf{k g} / \mathbf{m}^{3}\right]}\end{array}$ & $\begin{array}{c}\text { Sednutí } \\
\text { kužele } \\
{[\mathbf{m m}]}\end{array}$ \\
\hline AE 3,0 & 3,0 & 2320 & 200 \\
AE 5,5 & 5,5 & 2280 & 180 \\
AE 8,7 & 8,7 & 2170 & 200 \\
& & & \\
LPX7 3,4 & 3,4 & 2320 & 180 \\
LPX7 5,7 & 5,7 & 2270 & 190 \\
LPX7 9,2 & 9,2 & 2190 & 200
\end{tabular}

Jednotlivé směsi byly navrženy ve 3 různých variantách množství obsahu vzduchu v čerstvém betonu, jenž by reprezentovaly nízké, běžné a vyšší množství vzduchu. Důležitým aspektem bylo rovněž dosáhnout těchto podobných hodnot u obou druhů použitých provzdušňovacích př́ísad. Prakticky totožné hodnoty obsahu vzduchu v čerstvém betonu jsou patrné rovněž i z dosažených hodnot objemových hmotností čerstvého betonu u obou typů přísad. S rostoucím obsahem vzduchu v čerstvém betonu lze přirozeně sledovat klesající objemovou hmotnost betonu.

\section{Zkoušky na zatvrdlých betonech}

Tab. 3 Výsledky fyzikálních zkoušek zatvrdlých betonů.

\begin{tabular}{|c|c|c|c|c|c|c|c|}
\hline \multirow[t]{2}{*}{ Receptura } & \multirow[t]{2}{*}{$\begin{array}{c}\text { Obsah vzduchu } \\
\text { v čerstvém } \\
\text { betonu [\%] }\end{array}$} & \multicolumn{2}{|c|}{$\begin{array}{c}\text { Objemová hmotnost } \\
\text { zatvrdlého betonu } \\
{\left[\mathrm{kg} / \mathrm{m}^{3}\right]}\end{array}$} & \multicolumn{2}{|c|}{$\begin{array}{c}\text { Nasákavost } \\
{[\%]}\end{array}$} & \multicolumn{2}{|c|}{$\begin{array}{c}\text { Hloubka průsaku } \\
\text { tlakovou vodou } \\
{[\mathrm{mm}]}\end{array}$} \\
\hline & & 7 dní & 28 dní & 7 dní & 28 dní & 7dní & 28 dní \\
\hline $\mathrm{AE} 3,0$ & 3,0 & 2320 & 2310 & 6,0 & 6,0 & 15 & 12 \\
\hline $\mathrm{AE} 5,5$ & 5,5 & 2280 & 2290 & 5,8 & 6,0 & 12 & 11 \\
\hline $\mathrm{AE} 8,7$ & 8,7 & 2150 & 2160 & 6,3 & 6,3 & 10 & 9 \\
\hline LPX7 3,4 & 3,4 & 2320 & 2330 & 6,3 & 6,0 & 12 & 11 \\
\hline LPX7 5,7 & 5,7 & 2280 & 2280 & 6,4 & 6,0 & 15 & 14 \\
\hline LPX7 9,2 & 9,2 & 2180 & 2180 & 6,8 & 6,4 & 19 & 13 \\
\hline
\end{tabular}

Všechny výsledky zkoušek na zatvrdlých betonech (objemová hmotnost zatvrdlého betonu, nasákavost, hloubka průsaku tlakovou vodou, pevnost v tlaku a stanovení odolnosti betonu proti působení CHRL) byly stanoveny na třech zkušebních tělesech. Jednotlivé uvedené výsledky jsou průměrné hodnoty z těchto hodnot. Z výsledků lze vidět, že při stanovení hloubky průsaku tlakovou vodou dle ČSN EN 12390-8 jsou hodnoty průsaku mezi jednotlivými recepturami dost podobné (i v odlišném stáří). Podle obecného předpokladu by vyšší pórovitost betonu, tedy vyšší obsah vzduchu, měl způsobit nižší odolnost proti průsaku tlakovou vodou. V Tab. 3 ale vidíme, že $\mathrm{u}$ receptur $\mathrm{s}$ vyšším obsahem vzduchu $\mathrm{v}$ betonu nedochází $\mathrm{k}$ výraznějšímu průsaku tlakovou vodou (AE 8,7 - 9 mm a LPX7 9,2 - 13 mm po 28 dnech). Vysvětlením může být, že při vyšším obsahu uměle vneseného vzduchu do betonu je i obsah mikroskopického vzduchu v betonu vyšší, a to pak vede k narušení kapilární sítě původních pórů, které jsou spolu "provázané". Prosáknutí tlakové vody přes takto uměle vytvořenou sít' mikropórů je pak náročnější. Tyto hodnoty vypovídají, že i vyšší množství vzduchu v betonu nemá výrazný vliv na hodnoty průsaku tlakovou vodou [5], [6]. 


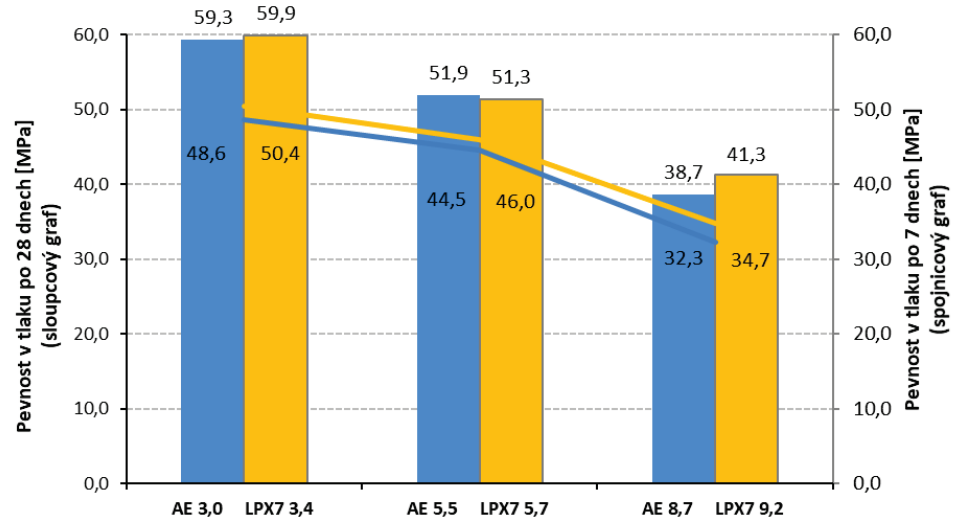

Obr. 2 Stanovení pevnosti v tlaku.

Z Obr. 2 lze vyčíst, že u obou typů provzdušňovacích př́sad ve všech časových horizontech s rostoucím obsahem vzduchu klesá pevnost v tlaku (vlivem vyššího obsahu vzduchu). Je patrné, že při využití provzd. přísady na bázi synt. tenzidů (LPX7) bylo dosaženo vyšších hodnot pevností v tlaku po 7 dnech (i přes vyšší obsah vzduchu v betonu než u provzd. přísad na bázi přírodních pryskyřic, např. AE 8,7 \% - 32,3 MPa a LPX7 9,2 \% $34,7 \mathrm{MPa}$ ). Tento trend lze pozorovat i po 28 dnech. Zde se již rozdíly více srovnávají (AE 8,7\% 38,7 MPa a LP X7 41,3 MPa. Dosažení vyšších pevností je spojováno podle některých autorů se vznikem odlišné sítě mikropórů než při použití přísad na bázi prrírodních pryskyřic [7].

\section{Stanovení odolnosti betonu proti působení CHRL po 28 dnech}

Tab. 4 Stanovení odolnosti proti působení CHRL.

\begin{tabular}{|c|c|c|}
\hline Receptura & $\begin{array}{c}\text { Obsah vzduchu } \\
\text { v čerstvém } \\
\text { betonu [\%] }\end{array}$ & $\begin{array}{c}\text { Množství odpadu } \\
\text { po } 100 \text { cyklech } \\
{\left[\mathrm{g} / \mathrm{m}^{2}\right]}\end{array}$ \\
\hline AE 3,0 & 3,0 & 4014 \\
\hline AE 5,5 & 5,5 & 2530 \\
\hline $\mathrm{AE} 8,7$ & 8,7 & 411 \\
\hline LPX7 3,4 & 3,4 & 4042 \\
\hline LPX7 5,7 & 5,7 & 3800 \\
\hline LPX7 9,2 & 9,2 & 3271 \\
\hline
\end{tabular}

V další částí experimentu bylo provedeno stanovení odolnosti proti působení CHRL (dle ČSN 731326 Z1, metoda A). V Tab. 4 lze pozorovat výrazné rozdíly v množství odpadu mezi recepturami. A to jak mezi druhy provzdušňovacích přísad, tak i mezi množstvím obsaženého vzduchu v čerstvém betonu. Ve všech variantách obsahu vzduchu dosahuje provzd. př́sada na bázi přírodních pryskyřic nižších hodnot odpadu po 100 cyklech působení CHRL než provzd. přísada na bázi synt. tenzidů. S častým požadavkem množstvím odpadu do $1000 \mathrm{~g} / \mathrm{m}^{2}$ pro stupeň vlivu prostředí XF4 nejlépe vyhověla pouze receptura AE 8,7 s celkovým množstvím odpadu $411 \mathrm{~g} / \mathrm{m}^{2}$ (s obsahem vzduchu 8,7\%). Ostatní receptury s obsahem vzduchu okolo 3,0 \% a 5,5\% nedosahovaly dostatečné účinnosti provzdušnění. Vzhledem k výsledkům odpadů lze některé receptury klasifikovat jako silně narušené až rozpadlé. Jednotlivé hodnoty odpadu mohou naznačovat, že nebylo vhodně zvoleno drobné kamenivo (kolísavé vlastnosti). Dále zde byla prokázána vyšší účinnost provzd. přísad na bázi př́rodních pryskyřic. Vyšší účinnosti je zřejmě dosaženo díky vytvoření odlišné homogennější sítě systému pórů (vyššímu zastoupení mikropórů) než u provzd. přísad na bázi synt. tenzidů [8]. 


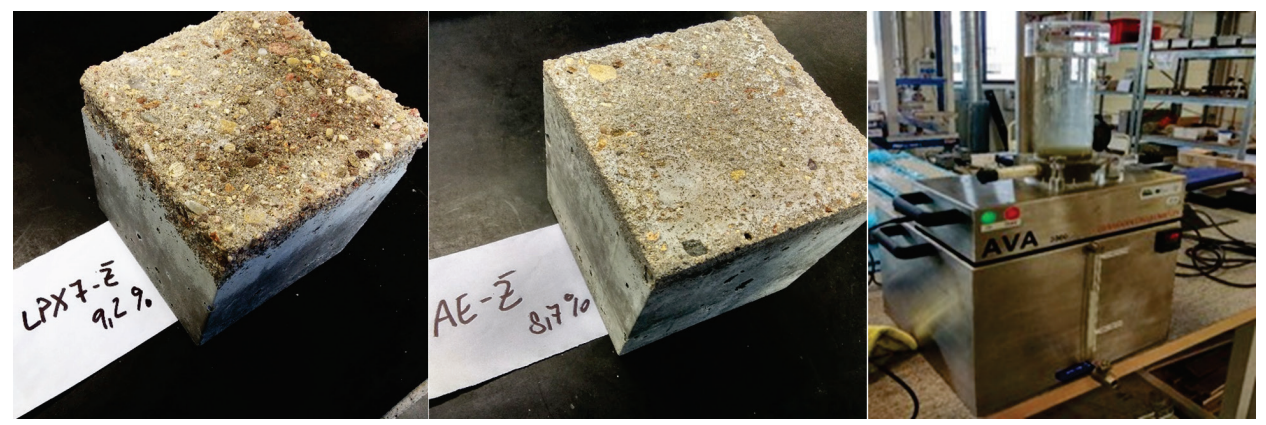

Obr. 3 Vzorky LPX7 9,2 a AE 8,7 po 100 cyklech působení odolnosti proti CHRL a zařízení AVA test.

\section{Air Void Analyzer (AVA)}

Pro stanovení obsahu vzduchových pórů a jejich velikostního rozložení v čerstvém betonu lze využít zařízení Air Void Analyzer. Toto zařízení umožňuje zjistit prostorové rozložení pórů spolu s jejich velikostí do $2 \mathrm{~mm}$. Postup této metody začíná odebráním vzorku přes ochranné síto o velikosti $6 \mathrm{~mm}$. Následně se vzorek vstříkne do zkušebního válce s Petriho miskou a mírně se míchá po dobu 30 s. Promícháním dochází k uvolnění pórů, které procházejí přes kapalinu. Kapalina má vhodnou viskozitu a hydrofilní charakter, díky které si bublinky vzduchu zachovávají stejnou velikost jako vzduchové póry v betonu. Bubliny následně stoupají podle Stokesova zákona (větší stoupají rychleji než menší). Stoupající bubliny naráží do obrácené Petriho misky a tím působí vztlak, čímž dochází ke snížení hmotnosti misky na senzorech váhy. Následně software vyhodnotí velikosti a distribuci pórů v čerstvém betonu. Zařízení je vidět na Obr. 3 [9].

\section{Vyhodnocení AVA test a porovnání s ostatními výsledky}

Tab. 5 Výsledky měření AVA testu.

Pozn.: A - Celkový obsah vzduchu v čerstvém betonu, $\mathrm{A}_{300}-$ Obsah mikroskopického vzduchu v čerstvém betonu.

\begin{tabular}{|c|c|c|c|c|}
\hline Receptura & $\begin{array}{c}\text { A - Tlaková metoda } \\
{[\%]}\end{array}$ & $\begin{array}{c}\text { A - AVA test } \\
{[\%]}\end{array}$ & $\begin{array}{c}\text { A300 - AVA } \\
\text { test [\%] }\end{array}$ & $\begin{array}{l}\text { Množství odpadu po } 100 \\
\text { cyklech stanovení odolnosti } \\
\text { proti působení } \mathrm{CHRL}\left[\mathrm{g} / \mathrm{m}^{2}\right]\end{array}$ \\
\hline $\mathrm{AE} 3,0$ & 3,0 & 2,2 & 0,2 & 4014 \\
\hline AE 5,5 & 5,5 & 3,9 & 0,7 & 2530 \\
\hline AE 8,7 & 8,7 & 5,4 & 1,9 & 411 \\
\hline LPX7 3,4 & 3,4 & 2,6 & 0,2 & 4042 \\
\hline LPX7 5,7 & 5,7 & 4,1 & 0,2 & 3800 \\
\hline LPX7 9,2 & 9,2 & 5,0 & 0,8 & 3271 \\
\hline
\end{tabular}

V porovnání jednotlivých metod pro stanovení obsahu vzduchu v čerstvém betonu je metoda AVA časově náročnější (cca $30 \mathrm{~min}$ ), ale nevyžaduje dodatečné zhutnění vzorku. Ovšem je důležité dbát na správný postup při odběru vzorku. Dále je metoda AVA vhodná pouze pro provzdušněné betony v rozsahu 3,0 - $10,0 \%$ celkového obsahu vzduchu v betonu.

Oproti tomu tlaková metoda vyžaduje finančně méně náročnější vybavení a časově zabere cca 5 min. Nevýhodou je, že vyžaduje zhutnění vzorku (stejně jak bude uložen v konstrukci).

V předchozí Tab. 5 vidíme porovnání zkoušek ovlivňující trvanlivostní parametry. Z výsledků je patrné, že podle zkušební metody AVA testu všechny receptury dosahují cca o 30 - 40 \% nižší obsah celkového naměřeného vzduchu v betonu než podle tlakové metody (ČSN EN 12350-7), přitom posloupnost hodnot je zachována [2]. Hodnoty mikroskopického vzduchu podle metody AVA test jsou kromě rec. AE $8,7\left(\mathrm{~A}_{300}=1,9 \%\right)$ rovněž velmi nízké okolo $0,2-0,8 \%$. Důvodem rozdílných výsledků mezi použitými metodami může být v samotném principu fungování AVA př́istroje [10]. 
Jednou z prríčin, proč u metody AVA mohlo být dosaženo nízkých hodnot mikroskopického vzduchu $\mathrm{A}_{300}$ je, že při měření dochází k uvolnění nejmenších pórů (pouze desítky mikronů) z odebraného vzorku v delším časovém horizontu. Když následně nedojde díky pomalému "stoupání" nejmenších mikropórů ke změně hmotnosti na Petriho misce, tak príistroj zkoušku ukončí. Což může vysvětlovat hodnoty naměřených výsledků, kdy nemuselo dojít k zaznamenání nejmenších mikropórů.

I přesto lze vidět, že hodnoty mikroskopického vzduchu $\mathrm{A}_{300}$ jednotlivých receptur si prakticky odpovídají s množstvím odpadu po stanovení proti působení CHRL. Jako např. u rec. AE $8,7\left(\mathrm{~A}_{300}=1,9 \%\right)$ je hodnota odpadu pouze $411 \mathrm{~g} / \mathrm{m}^{2}$, tak naopak u ostatních receptur s obsahem $\mathrm{A}_{300}$ okolo $0,2 \%$, hodnota odpadu často převyšuje $3000 \mathrm{~g} / \mathrm{m}^{2}$. To potvrzuje lepší účinnost provzd. přísad na bázi přírodních pryskyřic (při určitém obsahu vzduchu v betonu).

\section{ZÁVĚR}

Předložený článek pojednával o jednotlivých druzích a účincích provzdušňovacích přísad. Dále byla poukázána souvislost mezi některými fyzikálně-mechanickými vlastnostmi a obsahem vzduchu $\mathrm{v}$ betonu. Z výsledků stanovení odolnosti proti CHRL je patrné, že vyšší obsah vzduchu má zásadní vliv na trvanlivostní parametry, avšak často za cenu mechanických parametrů. V případě využití provzd. přísad na bázi přírodních pryskyřic bylo dosaženo nižších množství odpadu (AE $8,7=411 \mathrm{~g} / \mathrm{m}^{2}$ ) než u provzd. př́sad na bázi syntetických tenzidů. Vysvětlením může být, že provzd. přísady na bázi přírodních pryskyřic vytváří vhodnější pórovitou sít', umožňující lépe odolat krystalizačním tlakům solného roztoku.

Bylo zjištěno, že vyšší obsah vzduchu nemá zásadní vliv na hloubku průsaku tlakovou vodou. Dále byly popsány metody pro stanovení obsahu vzduchu v čerstvém betonu spolu s jejich výhodami a nevýhodami. V př́ípadě metody AVA testu bylo upozorněno na některé nedostatky metody, jež mohou ovlivnit výsledky parametrů celkového i mikroskopického obsahu vzduchu v betonu. Proto bude v navazujícím výzkumu využito další metody pro stanovení zjišt'ovaných parametrů touto metodou.

Následující výzkum bude zaměřen i na porovnání stejných provzd. přísad s dalšími druhy drobných kameniv z petrograficky jiných lokalit.

\section{Poděkování}

Př́spěvek byl vytvořen v rámci řešení projektu VUT specifického výzkumu FAST J 21 7427: Studium vlivu míry provzdušnění betonu na jeho objemové změny a odolnost vůči mechanické abrazi.

\section{Použité zdroje}

[1] LORI, E., M. TUNSTALL, M. TYLER LEY a W. SCHERER. Air entraining admixtures: Mechanisms, evaluations, and interactions. Cement and Concrete Research [online]. Netherland, Amsterdam: Elsevier, 2021, (150) [cit. 2021-11-28]. ISSN 0008-8846. Dostupné z: DOI:10.1016/j.cemconres.2021.106557

[2] ČSN EN 12 350-7. Zkoušení čerstvého betonu - Část 7: Obsah vzduchu - Tlakové metody. Praha: ÚNMZ, 2020.

[3] ČSN EN 12350-2. Zkoušení čerstvého betonu: Část 2: Zkouška sednutím. Praha: ÚNMZ, 2020.

[4] ČSN EN 12350-6. Zkoušení čerstvého betonu: Část 6: Objemová hmotnost. Praha: ÚNMZ, 2020.

[5] ČSN EN 12390-8. Zkoušení ztvrdlého betonu - Č́st 8: Hloubka průsaku tlakovou vodou. Praha: ÚNMZ, 2020.

[6] Air Entraining Admixture. ed. ZHANG, H.. Building Materials in Civil Engineering: Concrete [online]. Sawston, England: Woodhead Publishing, 2011, s. 81-149 [cit. 2021-11-28]. ISBN 978-1-84569-9550. Dostupné z: DOI:10.1533/9781845699567.81

[7] GAGNÉ, R. Air entraining agents. Science and Technology of Concrete Admixtures: Air entraining agents [online]. Sawston, England: Woodhead Publishing, 2016, s. 379-391 [cit. 2021-11-28]. ISBN 978-0-08-100693-1. Dostupné z: DOI:10.1016/B978-0-08-100693-1.00017-5

[8] ČSN 731326 Z1. Stanovení odolnosti povrchu cementového betonu proti působení vody a chemických rozmrazovacích látek. Praha: ÚNMZ, 1985.

[9] Germann Instruments: Air void analysis of fresh concrete: AVA-3000 [online]. Test Smart - Build Right [cit. 2021-11-28]. Dostupné z: https://germann.org/wp-content/uploads/2021/10/AVA-3000-TDS02.pdf

[10] L. URBÁNEK. Studium vlivu vneseného provzdušnění na parametry provzdušněných betonů. Brno, 2017. Bakalářská práce. Vysoké učení technické v Brně, Fakulta stavební, ÚTHD 